УДК [616-89.843:[364-786:008]]:[616.89-008.1:159.944.4]

ЮPOBА T. M.

https://orcid.org/0000-0003-0400-0852

https://doi.org/10.33577/2313-5603.36.2021.285-295

\title{
ПРОТЕЗУВАННЯ УЧАСНИКІВ БОЙОВИХ ДІЙ 3 АМПУТОВАНИМИ КІНЦІВКАМИ
}

Протезування - це спеціальний вид лікувальної та соціально-психологічної допомоги ампутантам, який спрямований на часткову або навіть повну компенсацію форм і функцій видалених кінцівок, які постраждали в результаті поранень і травм. Оскільки протезування тісно пов'язане не тільки $з$ травматологією, ортопедією, реконструктивною хірургією, а й з необхідністю ліквідації наслідків бойової психотравми, зняття депресивних станів, попередження ПТСР тощо, повноцінна реабілітація, абілітація потерпілого та його адаптація в соціумі вимагає комплексного підходу і залучення в цей процес військових психологів, соціологів і культурологів.

Ключові слова: ПТСР (посттравматичний стресовий розлад), бойова психічна травма, військові ампутанти, протезування, культурологічне забезпечення реабілітації.

Постановка проблеми та ї̈ актуальність. Практика протезування комбатантів, що постраждали в результаті бойових дій на Сході України показала, що сучасні протези - замінники видалених кінцівок, не тільки дозволяють повернути в суспільство в якості повноцінних його членів до $70 \%$ ампутантів, але й, у цілому ряді випадків, добитися особами з інвалідністю високих спортивних досягнень і успіхів в професії та бізнесі (Toxмачі A., 2017; Гузенкова Д., 2018; Бондарєв В., 2019; Копанєва К., 2016; Омельянчук О., 2017). В той же час, в умовах появи в українському суспільстві близько 5 тис. учасників АТО/ООС 3 інвалідністю (В Україні нарахували понад мільйон учасників бойових дій, 2018) і значного числа військовослужбовців-ампутантів виникла необхідність в нових поглядах на компенсаційні функції, які можуть бути надані постраждалим військовими психологами, соціологами і культурологами. Серед них - соціально-психологічний і культуролого-педагогічний супроводи реабілітаційного процесу, використання специфічних форм та методів роботи в

Юрова Тетяна Миколаївна, кандидат мистецтвознавства, викладач кафедри морально-психологічного забезпечення, Національна академія сухопутних військ імені гетьмана Петра Сагайдачного, м. Львів.

(C) Юрова Т. М., 2021 
морально-психологічній підтримці ампутантів, ліквідації наслідків БПТ і ПТСР, активне надання допомоги в адаптації ветеранів 3 інвалідністю в соціумі.

Аналіз попередніх досліджень $і$ публікацій. Проблеми фізичної і психологічної реабілітації ветеранів 3 ампутованими кінцівками досліджували І. Гайда, С. Болтівець, Ю. Бриндіков, Т. Цюпак, Ю. Цюпак, В. Драченко, О. Микитів, Ю. Кравчук, О. Пінчук, Л. Радецька, С. Коноваленко, О. Волянський, А. Кіх, І. Хоменко тощо. Вчені-лікарі та психологи Військово-медичного клінічного лікувально-реабілітаційного центру (м. Ірпінь) та Національного медичного університету імені О. Богомольця (м. Київ) розробили алгоритм лікувального та соціально-психологічного ведення пацієнтів 3 ампутацією кінцівок, запропонували комплексну реабілітацію ампутантів 3 диференційованим індивідуальним підходом та застосуванням сучасних технологій (Беспаленко $A$., Щеглюк О., Кіх А., Бур'янов О., Волянський О., Корченок В., Михайловська М., 2020). О. Волянський, А. Кіх, І. Хоменко розробляли методику реабілітації військовослужбовців після ампутації кінцівок (Волянський О., Кix А., Хоменко I., 2016). О. Микитів досліджував реабілітацію військовослужбовців після ампутації нижньої кінцівки на етапі підготовки до протезування (Микитів O., 2009). Актуальні для культурологів і «Методичні рекомендації щодо організації реабілітації військовослужбовців 3 ампутованими кінцівками» (Верба А., Казмірчук А., Хоменко I., Галушка А., Кіх А., Волянський О., Беспаленко А., Корченок В., 2017), розроблені Військово-медичним департаментом МО України, оскільки пропонують комплексний міждисциплінарний план підготовки пацієнтів до ампутації, реабілітації після операції і адаптації після протезування. Разом 3 тим, спостерігається певний дефіцит досліджень щодо створення комплексної системи реабілітації ампутантів і участі культурологів у процесі протезування.

Методика дослідження. Серед методів дослідження - моніторинг, метод взаємодії і розвитку, порівняльний метод, які вимагають, щоб усі явища, що досліджуються, вивчалися в динаміці і з урахуванням різноманіття зв'язків.

Метою $i$ завданнями дослідження є вивчення і узагальнення досвіду культуролого-педагогічної роботи щодо психологічного 
забезпечення підготовки постраждалих комбатантів до ампутації кінцівок, протезування, реабілітації та їх подальшої адаптації в соціумі.

Виклад основного матеріалу. До загальних універсальних компенсаційних функцій культурологічного супроводу військовослужбовця до та після ампутації відносяться: інформаційнокомунікативна, реабілітаційна, формуюча, адаптивна. Досвід соціально-психологічного та культуролого-педагогічного забезпечення підготовки постраждалих до ампутації та подальшого протезування показав, що перед ампутацією пацієнтові слід надавати певні процедурні освітні заходи щодо подолання тривоги, страху, психологічно-больових страждань, оптимізації його постопераційного відновлення, про шкоду вживання алкоголю та тютюну.

Головним завданням в цей період $є$ виявлення ресурсів, визначення форм та методів психологічної та соціальнокультурологічної підтримки постраждалого, забезпечення високої якості його життя.

Культуролого-педагогічне забезпечення реабілітації - це блок культурно-терапевтичних та педагогічних просвітницьких напрямів і методик, які мають лікувальні функції. До них відносяться:

- навчальні форми і методи, які допомагають пацієнтам в реабілітації та інтегруванні в соціум як повноправних членів суспільства;

- інформативно-мотиваційні методики, які здійснюються через розкриття позитивних перспектив реабілітації та абілітації, як на індивідуальному, так і на груповому рівнях;

- культурологічна та соціально-педагогічна робота щодо залучення постраждалих в оздоровчо-фізкультурну діяльність 3 метою мобілізації резервних можливостей ампутантів і стимуляції їх адаптивних процесів;

- арт-терапевтичні вправи, як допоміжні методи лікувальнореабілітаційної терапії, спрямовані на розвиток рухової активності, просторової орієнтації, подолання гіподинамії, агресії та інших негативних психологічних проявів почуттів і емоцій, формування естетичного середовища;

- кваліфікована і змістовна організація дозвілля і релаксу, як найважливіших складових у забезпеченні високої якості життя. 
Післяопераційне навчання ампутантів включає в себе:

- інформування про порядок, послідовність та зміст постопераційного догляду, методи лікування і реабілітації;

- знайомство 3 членами реабілітаційної команди, 3 якими доведеться надалі взаємодіяти;

- рекомендації щодо прискорення реабілітації, поліпшення здоров'я та формування навичок в нових умовах;

- демонстрація правильного використання медичного обладнання та ТЗР (технічних засобів реабілітаціі);

- ознайомлення 3 варіантами протезів, допомога в їх виборі, інформування про правила догляду та використання, симптоматику інфекцій;

- консультування $з$ питань харчування та модифікованих дієт, інформування про потенційну взаємодію ліків та продуктів харчування;

- попередження про шкоду тютюну та алкоголю;

- доведення методик контролю за болем, набряками, попередження гіпертонії та некрозів, дотримання гігієни шкіри, профілактики контрактури та тромбозу глибоких вен.

31 червня 2021 набрав чинності оновлений «Порядок забезпечення технічними та іншими засобами реабілітації осіб з інвалідністю» (Дї підприємства щодо забезпечення окремих категорій населення ТЗР, 2021), який встановлює не тільки безкоштовне державне забезпечення протезами учасників бойових дій, а й грошову компенсацію за виготовлення протезів своїми силами $і$ засобами в індивідуальному порядку в певних межах (Наказ Міністерства соціальної політики України від 06.08.2019 № 1208). I таке рішення проблеми протезування цілком обгрунтоване, оскільки вартість сучасних протезів досить висока. Наприклад, колінні модулі типу «C-Leg» та «Genium» коштують від 30.000 \$ до 90.000 \$ США (C-Leg в Украӥні, 2021). Учасник АТО Олександр Гудзь у 2016 р. став першим українським комбатантом, якому повністю за державні кошти в індивідуальному порядку японська фірма «Nabtesco» спроєктувала, виготовила і встановила протез ноги з мікропроцесором колінного суглоба NI-C313 (Шуткевич, 2016). I на сьогоднішній день протезування здійснюється в індивідуальному порядку, у творчій 
співпраці медиків, інженерів, дизайнерів, причому нерідко доводиться виготовляти кілька моделей для одного пацієнта, а на тренування і реабілітацію йдуть тижні і місяці. Оскільки таке протезування вкрай затратне, українські розробники протезів 3 самого початку бойових дій на Сході України прагнули вирішити проблему протезування учасників АТО/ ООС безпосередньо на Батьківщині. Наприклад, фахівці ТОВ «Парашара Індастріз» створили зразки, які не поступаються виробам зарубіжних виробників, але значно дешевше їх (Украӥнський ривок у сфері протезування: в Одесі представили колінні вузли вітчизняного виробництва, 2017).

У всьому світі вчені намагаються вдосконалити протези i забезпечити якість життя ампутантів. Так, фахівці з Піттсбурзького університету (штат Пенсільванія, США) створили протез, який дозволяє людині з ампутованою рукою відчути дотик пальців і імітує чутливість. Як повідомила газета «The Washington Post», американські винахідники вживили в мозок 30-річного Нейтана Коупленда крихітні електроди, здатні приймати сигнали 3 протеза (Йорик, 2016). Професор Массачусетського технологічного інституту Х'ю Герр, якого журнал «Тіmе» назвав «лідером біонічної епохи», здійснює перспективні дослідження в області біомехотроніки - технології, яка об'єднує фізіологію людини 3 електромеханікою. Результати його розробок підтверджені тим, що вчений, сам будучи ампутантом 3 двома ножними протезами, не тільки веде активний спосіб життя, а й займається альпінізмом і скелелазінням. 2015 року «Агентство перспективних дослідницьких проектів в області оборони» США (DARPA) провело випробувальний політ літака на біонічному авіастимуляторі F-35, яким за допомогою механічних рук управляла паралізована жінка. $\mathrm{C}$ багато прикладів, коли винахідники-самородки конструюють багатофункціональні біонічні протези з унікальним дизайном. До числа таких належать: створення 19-річним Девідом Агіларом біонічної руки з деталей конструктора Lego; протези ноги, спроектовані співачкою Вікторією Модеста, яка зуміла перетворити інвалідність на перевагу; дизайнерська знахідка супермоделі-ампутанткі Лорен Вассер - «дівчини 3 золотими ногами», яка прославилася завдяки своїми «luxuryпротезами»; біонічний протез руки, вдосконалений барабанщиком 
Джейсоном Барнсом до такої міри, що він став грати на ударних інструментах швидше за звичайних музикантів (Зуйкова, 2021). Українська компанія «Ортотех-сервіс ГмбХ» ще у 2015 р. приступила до виготовлення для учасників АТО / ООС біонічних протезів верхніх кінцівок 2-го покоління. Дана біонічна рука за функціональністю на кілька порядків вище за ті, що виготовлялися в Україні раніше. Вона має 14 видів захватів і забезпечує виконання маніпуляцій, таких, як шнурівка взуття, користування дверним ключем, робота 3 комп'ютерною мишею, утримання крихких речей тощо, що вимагають високої точності рухів (Стеценко, 2015). Усі подібні вироби відрізняє сучасний дизайн, який теж сприяє успішній реабілітації ампутантів.

Оскільки протезування лише частково допомагає у психологічній реабілітації постраждалих комбатантів, сучасні митці знаходять нові культурологічні резерви щодо поліпшення результатів реабілітаційного процесу. Українські фахівці, взявши за основу творчі здобутки дизайнерів-протезистів Канади Макколі Уаннера і Райана Паліброда зі студії «Alleles Design», почали перетворювати протези нижніх кінцівок на інноваційний і модний аксесуар, прикрашаючи їх авторськими візерунками та яскравими мотивами, які нагадують сучасні, красиві і стильні татуювання. Ця оригінальна концепція покликана допомогти людям 3 інвалідністю не лише прийняти своє проблемне становище, але і знаходити в цьому певні позитивні моменти.

Україні варто також перейняти світову тенденцію інклюзивності та позитивного сприйняття людей 3 тими чи іншими особливостями і навіть фізичними вадами («body-positivity») 3 досвіду, наприклад, американської компанії Mattel i японської Smart doll, які сьогодні здійснюють для дітей випуск ляльок 3 ампутованими кінцівками. Таким чином, починаючи 3 дитинства у населення відбувається формування оцінного психологогуманітарного сприйняття того, що бути особливим - це нормально, і що в цьому є навіть свої певні переваги. Прототипами деяких випусків нерідко стають реальні особистості, як, наприклад, для ляльки Барбі з лінійки «Fashionistas 2019» такою людиною стала Паола Антоніні - бразильська модель, яка втратила ногу в результаті автокатастрофи (Modelo Paola Antonini comemora 
lançamento de Barbie com deficiência física, 2019). Соціальнопсихологічні дослідження показали, що саме естетична і культурнопедагогічна складова формування сприйняття соціумом ампутантів не як неповноцінних осіб, а як людей з певними особливостями, $\epsilon$ найбільш прийнятною і ефективною в справі їх реабілітації та подальшої адаптації в суспільстві.

Висновки: Культурологічно-педагогічне забезпечення психологічної реабілітації постраждалих комбатантів до і після ампутації досягається участю військових культурологів в складі реабілітаційної команди в морально-психологічній підтримці ампутантів, навчально-просвітницькій роботі, в залученні до цього процесу членів сімей пацієнтів, їх бойових друзів, представників культурномистецької громадськості, релігійних конфесій, а також забезпеченням належного рівня якості життя ветеранів.

Культурологічно-педагогічний супровід реабілітаційного процесу специфічними формами і методами, використання в цьому питанні зарубіжного досвіду сприяе не тільки формуванню мотивації до якнайшвидшої адаптації в соціумі, а й результативності в рішенні життєвих проблем осіб з обмеженими фізичними можливостями.

\section{Використані посилання}

Тохмачі А. (2017) «Медалі - медалями, а людей треба берегти», уповноважений із питань реабілітації військових про «Ігри нескорених» URL: https://hromadske.ua/posts/ukrainski-viiskovi-na-ihrah-neskorenih [Дата зверн.: 16.08.2021 p.].

Гузенкова Д. (2018) «Ти крутий!» - сказав онук Пандраку URL: https://rivnepost.rv.ua/news/ti-krutiy-skazav-onuk-pandraku [Дата звернення: 16.08.2021 p.].

Бондарєв В. (2019) 3 ампутованою ногою він рік прослужив на Сходi, сьогодні Батьківщину захищає його син. URL:https://suspilne.media/3432-zamputovanou-nogou-vin-rik-prosluziv-na-shodi-sogodni-batkivsinu-zasisae-jogo$\sin$ / [Дата звернення: 16.08.2021 p.].

Омельянчук О. (2017) «Протез боронити державу не заважає»: волонтер розповіла три історії бійців АТО, які після ампутащії повернулися на передову [online] URL: http://patrioty.org.ua/blogs/protez-boronyty-derzhavu-ne-zavazhaievolonter-rozpovila-try-istorii-biitsiv-ato-iaki-pislia-amputatsii-povernulysia-naperedovu-188475.html [Дата звернення: 16.08.2021 p.].

Копанєва К. (2016) Герой АТО, чернівчанин Сергій Козак із пришитою ногою повернувся на фронт URL: https://bukinfo.com.ua/show/news?lid=70886 [Дата звернення: 16.08.2021р.]. 
В Украйні нарахували понад мільйон учасників бойових дій (2018) URL: https://www.ukrinform.ua/rubric-society/2460726-v-ukraini-narahuvaliponad-miljon-ucasnikiv-bojovih-dij.html [Дата звернення: 16.08.2021р.].

Беспаленко А., Щеглюк О., Кіх А., Бур'янов О., Волянський О., Корченок В., Михайловська М. (2020) Алгоритм реабілітації військовослужбовців з ампутацією кінцівок на основі мультипрофесійного та індивідуального підходу, Український журнал військової медицини, №1, С. 64 - 72.

Микитів О. (2009). Роль фізичної реабілітації у вирішенні проблем осіб після ампутації нижньої кінцівки на етапі підготовки до протезування, Молода спортивна наука України, Львів, Львівський державний університет фізичної культури, Т. 3. С. 111-115.

Волянський О., Кіх А., Хоменко І. (2016) Організація реабілітації військовослужбовців з ампутаціями кінцівок, Проблеми військової охорони здоров'я, Вип. 46, С. 28-34.

Верба А., Казмірчук А., Хоменко І., Галушка А., Кіх А., Волянський О., Беспаленко А., Корченок В. (2017). Методичні рекомендації щзодо організаиії реабілітації військовослужбовиів з ампутованими кінцівками. Київ, 60 с.

Заболотна Р. (2015) Владика Василь (Тучапещь) відвідав поранених у Харківському військовому госпіталі URL: http://news.ugcc.ua/news/vladika_vasil_tuchapets_vidvidav_poranenih_u_harkivskomu_viyskovomu_gospitali_74953.html [Дата звернення 16.08.2021 p.].

ФФУ привітала військовослужбовиів з днем збройних сил України (2018) URL: https://football.ua/ukraine/378623-ffu-privitala-vijjskovosluzhbovciv-z-dnemzbrojjnikh-sil-ukrajini.html [Дата звернення: 16.08.2021 p.].

Міжнародний день відмови від куріння (2019) URL: https://vbag.pmsd.org.ua/novyny-zakladu/mizhnarodnyj-den-vidmovy-vid-kurinnia/ [Дата звернення: 16.08.2021 p.].

Савченко О. Олег Сухарєв, боєцьь батальйону «Айдар» (2014) URL: https://focus.ua/ukraine/314168 [Дата звернення: 16.08.2021р.].

Маловідомі факти про протези ніг (2014) URL:https://www.bbc.com/ukrainian/ukraine_in_russian/2014/08/140812_ru_s_prosthetic_legs_facts [Дата звернення: 16.08.2021 p.].

Дії підприємства щзодо забезпечення окремих категорій населення ТЗР (2021) URL: https://www.ispf.gov.ua/diyalnist/zabezpechennya-tehnichnimi-zasobamireabilitaciyi/diyi-pidpriyemstva-shchodo-zabezpechennya-okremih-kategorijnaselennya-tzr [Дата звернення: 16.08.2021 p.].

Наказ Міністерства соціальної політики України «Про організацію забезпечення окремих категорій населення технічними та іншими засобами реабілітаиії» від 06.08.2019 № 1208 URL: https://zakon.rada.gov.ua/laws/show/z100319\#Text [Дата звернення: 16.08.2021 р.].

Шуткевич О. (2016) Молодому вінничанину, який втратив ногу в АТО, розробили унікальний протез URL: https://day.kyiv.ua/uk/news/271016-molodomuvinnychanynu-yakyy-vtratyv-nogu-v-ato-rozrobyly-unikalnyy-protez [Дата звернення: 16.08.2021 p.].

Украӥнський ривок у сфері протезування: в Одесі представили колінні вузли вітчизняного виробництва (2017) URL: https://infoprostorodessa.wordpress.com/2017/02/07/украинский-рывок-в-сфере-протезирова/ [Дата звернення: 16.08.2021р.]. 
C-Leg в Україні (2021) URL: http://www.dopomoga.biz.ua/cat_11.htm [Дата звернення: 16.08.2021 р.].

Йорик А. (2016) Вчені розробили протези, які відчувають URL: https://yorick.kz/uchyonye-razrabotali-chuvstvitelnye-protezy/ [Дата звернення: 16.08.2021р.].

Зуйкова А. (2021) Біонічні протези: на що вони здатні, $і$ коли ми станемо кіборгами? URL: https://trends.rbc.ru/trends/industry/5e91e02b9a79474e8cb6d892 [Дата звернення: 16.08 .2021 р.].

Стеценко О. (2015) В Україні вироблятимуть біонічні протези рук для учасників АTO URL: https://www.pravda.com.ua/rus/news/2015/08/7/7077021/ [Дата звернення: 16.08 .2021 р.].

Parizhanka A. (2017) Фірма, яка змогла перетворити протези ніг в модний аксесуар. URL: https://fishki.net/2315663-firma-kotoraja-smogla-prevratity-protezynog-v-modnyj-aksessuar.html [Дата звернення: 16.08.2021 p.].

Modelo Paola Antonini comemora lançamento de Barbie com deficiência física (2019) URL: https://caras.uol.com.br/atualidades/modelo-paola-antonini-comemoralancamento-de-barbie-com-deficiencia.phtml [Дата звернення: 16.08.2021р.].

\section{References}

Tokhmachi A. (2017) «Medals - medals, and people must be protected», - the Commissioner for Rehabilitation of the military about the «Games of the Unconquered» URL: https://hromadske.ua/posts/ukrainski-viiskovi-na-ihrah-neskorenih [Date of application 16.08.2021].

Guzenkova D. (2018) «You're cool!» - said Pandrak's grandson [online] URL: https://rivnepost.rv.ua/news/ti-krutiy-skazav-onuk-pandraku [Date of application 16.08.2021].

Bondarev V. (2019) With an amputated leg, he served a year in the east, today the homeland, defended by his son [online] URL: https://suspilne.media/3432-zamputovanou-nogou-vin-rik-prosluziv-na-shodi-sogodni-batkivsinu-zasisae-jogo-sin/ [Date of application 16.08.2021].

Omelyanchuk O. (2017) «Prosthesis does not prevent defending the state»: Volunteer told three stories of anti-terrorist operation fighters who returned to the front line after amputation [online] URL: http://patrioty.org.ua/blogs/protez-boronytyderzhavu-ne-zavazhaie-volonter-rozpovila-try-istorii-biitsiv-ato-iaki-pislia-amputatsiipovernulysia-na-peredovu-188475.html [Date of application 16.08.2021].

Kopaneva K. (2016) The hero of the anti-terrorist operation, Serhiy Kozak from Chernivtsi, returned to the front with his leg sewn on URL: https://bukinfo.com.ua/show/news?lid=70886 [Date of application 16.08.2021].

There are more than a million participants in hostilities in Ukraine (2018) URL: https://www.ukrinform.ua/rubric-society/2460726-v-ukraini-narahuvali-ponad-miljonucasnikiv-bojovih-dij.html [Date of application 16.08.2021].

Bespalenko A., Shcheglyuk O., Kikh A., Buryanov O., Volyansky O., Korchenok V., Mikhailovska M. (2020) Algorithm for rehabilitation of servicemen with limb amputation based on multiprofessional and individual approach, Ukrainian Journal of Military Medicine, №1, p. 64-72.

Mykytiv O. (2009) The role of physical rehabilitation in solving problems of persons after amputation of the lower extremity at the stage of preparation for prosthetics, 
Young Sports Science of Ukraine, Lviv, Lviv State University of Physical Culture, Vol. 3. p. 111-115.

Volyansky O., Kikh A., Khomenko I. (2016) Organization of rehabilitation of servicemen with limb amputations, Problems of military health care, Vol. 46, p. 28-34.

Verba A., Kazmirchuk A., Khomenko I., Galushka A., Kikh A., Volyansky O., Bespalenko A., Korchenok V. (2017) Methodical recommendations on the organization of rehabilitation of servicemen with amputated limbs. Kyiv, $60 \mathrm{p}$.

Zabolotna R. (2015) Bishop Vasyl (Tuchapets) visited the wounded in the Kharkiv military hospital URL: http://news.ugcc.ua/news/vladika_vasil_tuchapets_vidvidav_poranenih_u_harkivskomu_viyskovomu_gospitali_74953.html [Date of application 16.08.2021].

UFA congratulated servicemen on the Day of the Armed Forces of Ukraine (2018) URL: https://football.ua/ukraine/378623-ffu-privitala-vijjskovosluzhbovcivz-dnem-zbrojjnikh-sil-ukrajini.html [Date of application 16.08.2021].

International Day of Smoking Cessation (2019) URL: https://vbag.pmsd.org.ua/novyny-zakladu/mizhnarodnyj-den-vidmovy-vid-kurinnia/ [Date of application 16.08.2021].

Savchenko O. Oleg Sukharev, fighter of the Aidar Battalion (2014) URL: https://focus.ua/ukraine/314168 [Date of application 16.08.2021].

Little-known facts about leg prostheses (2014) URL: https://www.bbc.com/ukrainian/ukraine_in_russian/2014/08/140812_ru_s_prosthetic_legs_facts [Date of application 16.08.2021].

Actions of the enterprise to provide certain categories of the population TZR (2021) URL: https://www.ispf.gov.ua/diyalnist/zabezpechennya-tehnichnimi-zasobamireabilitaciyi/diyi-pidpriyemstva-shchodo-zabezpechennya-okremih-kategorij-naselennyatzr [Date of application 16.08.2021].

Order of the Ministry of Social Policy of Ukraine «On the organization of providing certain categories of the population with technical and other means of rehabilitation» from 06.08.2019 № 1208 URL: https://zakon.rada.gov.ua/laws/show/z1003-19\#Text [Date of application 16.08.2021].

Shutkevich O. (2016) A young Vinnytsia resident who lost his leg in the antiterrorist operation developed a unique prosthesis URL: https://day.kyiv.ua/uk/news/271016-molodomu-vinnychanynu-yakyy-vtratyv-nogu-v-ato-rozrobyly-unikalnyy-protez [Date of application 16.08.2021].

Ukrainian breakthrough in the field of prosthetics: knee joints of domestic production were presented in Odessa (2017) URL: https://infoprostorodessa.wordpress.com/2017/02/07/украинский-рывок-в-сфере-протезирова/ [Date of application 16.08.2021].

C-Leg in Ukraine (2021) URL: http://www.dopomoga.biz.ua/cat_11.htm [Date of application 16.08.2021].

Yorik A. (2016) Scientists have developed prostheses that feel URL: https://yorick.kz/uchyonye-razrabotali-chuvstvitelnye-protezy/ [Date of application 16.08.2021].

Zuikova, A. Bionic prostheses: what are they capable of, and when will we become cyborgs? (2021) URL: https://trends.rbc.ru/trends/industry/5e91e02b9a79474e$8 \mathrm{cb6d} 892$ [Date of application 16.08.2021]. 
Stetsenko O. (2015) Bionic hand prostheses for ATO participants will be produced in Ukraine URL: https://www.pravda.com.ua/rus/news/2015/08/7/7077021/ [Date of application 16.08.2021].

Model Paola Antonini celebrates the launch of Barbie with physical disability (2019) URL: https://caras.uol.com.br/atualidades/modelo-paola-antonini-comemoralancamento-de-barbie-com-deficiencia.phtml [Date of application 16.08.2021].

\section{Yurova T.}

\section{PROSTHETICS FOR COMBAT PARTICIPANTS WITH AMPUTED LIMBS}

The result of the hybrid war in Donbass was the appearance in Ukraine of a large number of amputees. Prosthetics, as a special type of medical and socio-psychological assistance to victims, is associated not only with traumatology, orthopedics, reconstructive surgery, but also with the need to eliminate the consequences of combat mental trauma, relieve depressive conditions, and prevent PTSD. Full rehabilitation, habilitation of victims and their adaptation in society require an integrated approach and the involvement of military psychologists, sociologists and cultural scientists in this process.

Culturological and pedagogical support of rehabilitation is a block of cultural, therapeutic and pedagogical educational directions and techniques that have therapeutic functions. These include:

- educational forms and methods that help patients in rehabilitation and integration into society as full members of society;

- informative and motivational techniques, which are carried out through the disclosure of positive prospects for rehabilitation and habilitation, both at the individual and at the group level;

- culturological and socio-pedagogical work to involve victims in the healthimproving, physical and sports field of activity in order to mobilize the reserve capabilities of amputees and stimulate their adaptive processes;

- art therapy exercises as auxiliary methods of therapeutic and rehabilitation therapy aimed at developing motor activity, spatial orientation, overcoming lack of movement, aggression and other negative psychological manifestations of feelings and emotions, forming an aesthetic environment;

- qualified and meaningful organization of leisure and relaxation, as the most important components in ensuring a high quality of life.

Since prosthetics only partially helps in the psychological rehabilitation of persons with disabilities, modern designers are turning prostheses into an innovative and fashionable accessory. This concept is designed to help amputees find a positive in their position. Cultural and pedagogical support of the rehabilitation process contributes to the formation of motivation for successful adaptation in society, helps in solving the life problems of disabled people.

Keywords: PTSD (post-traumatic stress disorder), combat mental trauma, military amputees, prosthetics, prostheses, cultural rehabilitation, adaptation. 